\title{
Highlighting Determinants of Financial Performance of the Jordanian Financial Sector: Panel Data Approach
}

\author{
Hussain A. Bekhet ${ }^{1}$, Jad Alkareem Alhyari $^{1}$ \& Nora Yusma Mohamed Yusoff ${ }^{1}$ \\ ${ }^{1}$ Universiti Tenaga Nasional, Kajang, Malaysia \\ Correspondence: Hussain A. Bekhet, Universiti Tenaga Nasional, Kajang 43300, Selangor, Malaysia.
}

Received: August 16, 2020

Accepted: October 12, 2020

Online Published: December 15, 2020

doi:10.5430/ijfr.v11n6p237

URL: https://doi.org/10.5430/ijfr.v11n6p237

\begin{abstract}
This study was aimed at identifying the main determinants of financial performance in Jordanian financial sector over 2005-2016 periods. Profitability ratio (return on equity) was used as a proxy of financial performance measurement. Meanwhile, firms' specific variables, macroeconomic variables and non-economic factors were used as explanation variables. Panel data set for four sub-sectors of financial sector over the above period were used. Pooled OLS, Fixed effect, random effects techniques with Heteroskedasticity and Serial Correlation Robust Standard Error estimation methods were employed. The empirical results showed that liquidity and leverage were the key determinants of financial performance while risk, macroeconomic factors and non-economic factors do not affect the financial performance of financial sector in Amman Stock Exchange. Therefore, the results conclude that financial performance is mainly driven by firm specific factors (company characteristics). Thus, a sound financial performance can be obtained by giving attention to firm specific variables.
\end{abstract}

Keywords: financial performance, world financial crisis, Arabic spring, panel data, Jordan

JEL Classification: C33, G14, G21, G32

\section{Introduction}

Financial performance is a process of measuring the results of a firm's policies and operations in monetary terms. It is used to measure firm's overall financial health over a given period of time and to compare similar firms across the same industry as well as industries or sectors in aggregation. The performance of firms also reflects the main outcomes achieved by individuals or groups in an organisation according to their responsibility and authority in achieving specific targets legally. Therefore, performance gauges the ability of an organisation in managing its resources to improve its competitive advantage utilising several ways (Almajali et al., 2012). Indeed, there are many ways to measure financial performance, but all measures should be taken in economic aggregates and monetary assessment. Among the key economic factors widely used in assessing the financial performance are interest rate, GDP, consumer price index (CPI), stock market index and unemployment, which can show a negative or positive threat to a company's performance (Egbunike \& Okerekeoti, 2018). Also, the performance of a company is affected by macro-economic factors (government policies and regulation, suppliers, social, environmental, political conditions and competitors exist outside the firm control) and micro economic factors (production, leadership product, demand, organisational culture and manufacturing (quality) that exist under the management control] (Dioha et al, 2018; Egbunike \& Okerekeoti, 2018).

In addition to that, financial performance plays a significant role in determining the financial weakness or strength of a company besides identifying the future growth in a short-term and long-term with the help of financial performance indicators (Kumar, 2014). Besides, according to Abebe and Abera (2019), the financial institutions in the economy of a country play indispensable role for enhancing the effectiveness and efficiency of financial system through intermediation, risk transfer and saving mobilisation. They emphasised that all of subsectors of financial sector play vital role in every economy. For instance, financial stability in the financial markets can be caused by the role of insurers through risk absorption, which provides a sense of peace to the development of an economic as it provides long-term funds. This has been made evident from the crises in Russia, East Asia, Latin America and universe financial crisis in 2007 (Egbunike \& Okerekeoti, 2018; Issah and Antwi, 2017; Bekhet \& Yasmin, 2014). 
The world in the year of 2008 was a turning point. Most countries and industries have been negatively influenced by global financial crisis due to the open economy system that most countries have in the globalisation era (Nour \& Sharabati, 2014). Also, the world economic crisis affected countries in the Middle East in much the same way it affected those in the West, and the responses of the governments of these countries were generally consistent with those in other parts of the developed world (Salah, 2010).

Jordan's economy has lost many financial benefits during the last three decades from the hassles and warfare happened in the Middle East. For instance, Gulf Countries' council reduced the recruitment of Jordanian employees, "oil supplements and traditional export market" after Gulf-War (1991). Jordan's economy had another tragedy after Iraqi-War (2003) that neither tremendous oil grants nor heavily discount on oil price existed (Bekhet \& Matar, 2013). In addition, the Jordanian economy was threatened by huge government debt and several economic problems in terms of macroeconomic variable (Bekhet and Al-Smadi, 2015; Bekhet, Alsmadi \& Khudari, 2020). In August 2019, Jordanian public debts have reached 41.6 USD billion (IMF, 2019). Negative performance has been recorded according to ASE indicators during the last few years, which was caused by the combination of international, financial and economic aspects such as high level of public debt, budget deficits and reduced foreign reserved (Bekhet and Al-Smadi, 2015; Bekhet and Matar, 2012). Therefore, IMF (2019) aimed to stabilise public debt at $94.6 \%$ of GDP. This had led most Jordanian companies to have vulnerable financial performance and their capability to generate positive revenues was weak through the last years (Matar and Eneizan, 2018). Furthermore, Bekhet and Matar (2013) pointed out the vital role of Amman Stock Exchange (ASE) and confirmed that the role for the clear regulations, innovations and development have been made by consecutive governments. However, the indicators of ASE recorded a negative performance in last few years (ASE, 2019). For instance, due to the changes occurred in the number of listed shares and share prices, market capitalisation, which is considered as a vital indicator of ASE performance, has dropped as a percentage of GDP from 326.6\% in 2005 to $70.7 \%, 65.1 \%$ and $61.8 \%$ in 2015, 2016 and 2017, respectively. This decrease included all ASE sectors (industry sector, services sector and financial sector including banks, insurance, diversified financial services and real estate). Figure 1 reveals the market capitalisation of all sectors in ASE as a percentage of GDP during the period from 2005 to 2016.

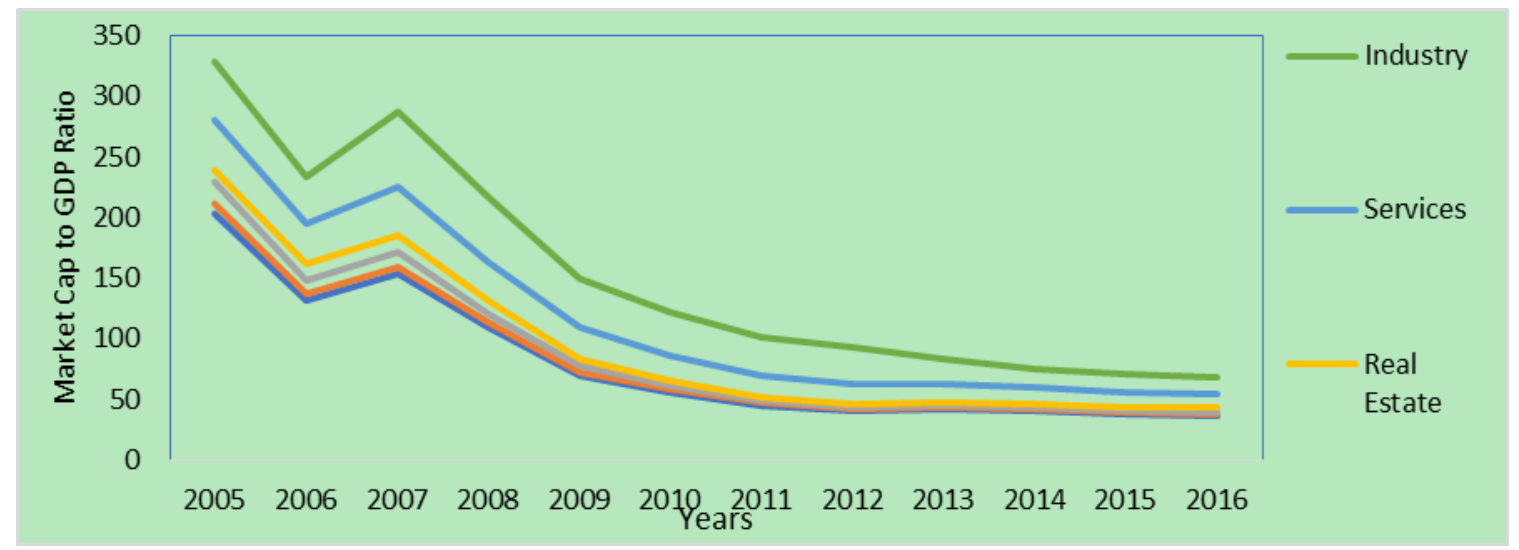

Figure 1. Market capitalisation of all sectors in ASE for the (2005-2016) period

Source: ASE (2019), available online at: http://www.ase.com.jo

Simultaneously, return on equity (ROE) has decreased within the last five years (ASE, 2019). However, there was no ideal number targeted by specific company. Subsequently, most companies plan ROE is to be as high as possible. High ROE with great liabilities could mean that there is less equity invested in the company. Accordingly, the company's capability to use its borrowed money in a proper manner reflects whether the company has positive or negative situation in terms of ROE (Gallo, 2016). In Jordan, it is clear that firm specific factors (e.g. liquidity) are highly correlated with the level of total income received by the financial companies (e.g. banks) (Samhan \& Al-khatib, 2015). In the same line, macroeconomic factors such as GDP and inflation rate play significant and negative roles in determining the financial performance of financial companies (Kharawish et al., 2011). Simultaneously, Egbunike \& Okerekeoti (2018) emphasised that both micro and macro factors interact with each other to determine the financial performance of a firm. Besides, Alquadah \& Malkawi (2014) pointed out that financial performance is impacted by external factors. For instance, the financial crisis influenced the financial 
performance measured by return on assets of Jordanian banks negatively as it decreases the liquidity owned by individuals, corporations and governments, thus negatively reflected on economic and services activities. In the same vein, Arab Spring had a negative financial and economic impact on most Arab countries. Also, in Jordan's case, Arab spring and the (Herak) in Jordan had negative influenced the business and investment activities (Abumostufa, 2016). Based on the aforementioned, this study aims to reanalyse the relationship between financial performance (ROE) and its determinants regarding all sub-sectors of financial sector in Amman Stock Exchange. Furthermore, it measures the stability of financial performance in Jordanian economy to find out which factors are the most important in improving the financial performance of ASE. In general, the main objective of the current study is to explore the interrelationship between company characteristics, macroeconomic factors, non-economic factors and financial performance of sub-sectors of financial sector in Amman Stock Exchange. To formulate the hypotheses, this paper intends to achieve the following specific objectives.

1- To investigate the key determinants of company characteristics [Risk (RS), Liquidity (LQ) and Leverage (LV)] that affects the financial performance of financial sector in ASE.

2- To evaluate the key determinants of macroeconomic factors [GDP (Y) and Inflation (INF)] that affect the financial performance of financial sector in ASE.

3- To examine the key determinants of non-economic factors [World financial crisis (FC) and Arab spring (AS)] that affect the financial performance of financial sector in ASE.

In order to measuring above objectives, this paper was structured as follows: In section 2, the theoretical framework of the study including Arbitrage Pricing Theory (APT) and Resource-Based View Theory (RBV) are discussed. Section 3 discusses the Literature review including the relationships between company specific factors, macroeconomic factors and non-financial factors as well as company financial performance. Section 4 defines data sources and variables' definition as balanced panel data for four sub-sectors of financial sector (banks, insurance, diversified financial services and real estate sub-sectors) over the period of 2005 to 2016. Section 5 highlights the model specification and methodology. Section 6 discusses the empirical results analysis. Section 7 summarises the conclusion and policy implications with recommendations.

\section{Theoretical Framework}

This current study was anchored on Arbitrage pricing theory (APT), which was used to explain the interaction of the external environment (macroeconomic and non-economic factors) with the financial performance of financial sector in ASE. Meanwhile, Resource-Based View Theory (RBV) was employed to discuss how internal factors (firm specific factors) determine the outcome of the firm.

\subsection{Arbitrage Pricing Theory}

In regards of financial markets, APT suggested that "the expected return of financial asset can be modelled as a linear function of various microeconomic factors or theoretical market indices" (Al-Smadi, 2015; Matar, 2014). This theory relates the factor's risk of an investment to its expected rate of return. According to Grinblatt and Titman (2002), empirical test of the APT can investigate the following implications: (1) The required return of portfolio where betas are equal to zero; (2) Securities required return raise in a linear way with the increase of a given factor beta. (3) Stocks have no other characteristics except the factor betas impact expected return.

Besides, complication of decisions under risk and uncertainty is the main part of this theory. This means that investment risks occur due to market determinant changes such as equity risk and interest rate, which are crucial for investors while making investment decisions (Al-Smadi, 2015). Consequently, there are several questions that need to be answered in terms of significance of APT. First, Arbitrage Pricing Model is multi-factor model (Watson and Head, 2010). Thus, such theory considers as a motivation and can express the relationship between the financial performance and microeconomic factors in terms of market and particular risk characteristics in emerging markets including Amman Stock Exchange. Second, the fundamental idea of APT is concentrated on the ability of modelling expected return as a linear function of several macroeconomic variables (Matar, 2014). Therefore, beside the current study, the Arbitrage Pricing Theory has been applied by several previous studies in numerus stock exchanges (e.g. Al-Najjar, 1998; Connor and Korajczyk, 1986). In the context of Jordan, Ramadan (2012) investigated the applicability of the APT in Amman Stock Exchange. The results showed that APT is applicable in ASE. Thus, APT theory is the most relevant for this current study due to two reasons (Matar; 2014): (a) APT reflects the verity of Jordanian economy; (b) The fundamental idea of APT is concentrated on the ability of modelling expected return as a linear function of several macroeconomic variables. 


\subsection{Resource-Based View Theory}

The conceptual framework of the current study was based on Resource-Based View Theory. It supposes that internal factors of an organisation are mainly responsible in generating superior performance and sustainable competitive advantage (Kapelko, 2006). Its means that there is a link between performance and company's internal resources (Egbunike \& Okerekeoti, 2018). Therefore, company's resources can build a competitive advantage for these companies (Egbunike \& Okerekeoti, 2018; Hunt, 1999). Consequently, RBV assumes that a firm specific characteristic influences the change in its performance (Slijper, 2017). Also, this theory claims that the target of a company and its desired outcomes of managerial effort is a sustainable competitive advantage as it allows the company to earn economic returns (Kapelko, 2006).

Barney (1991) asserted that the existence of heterogeneity is important within different companies to be able to demonstrate the observed difference of performance among companies. Otherwise, effectiveness and efficiency of companies could be improved to the same extent if all companies possess similar resources and implement the same strategies. Therefore, the end result will be without either performance superiority or competitive advantage (Egbunike \& Okerekeoti, 2018). Therefore, RBV discusses economic profits or delivery of sustained above-normal returns regarding to company's bundle of resources that are inimitable, valuable, non-substitutable and rare (Toms, 2010). In other words, Egbunike \& Okerekeoti (2018) asserted that sustained competitive advantages can be generated by company resources that possess four necessary attributes: (1) Being valuable (improving the efficiency and the effectiveness of the company by enabling it to implement particular strategies); (2) Being rare (this assertion does not ignore the significance of valuable but common resources), but such resource could ensure the survival of the company while does not lead to competitive superiority for the company; (3) Being imperfectly imitable (as a result of "unique historical condition, causal ambiguity between the competitive advantage and the resource giving rise to it, as well as social complexity of the resource generating competitive advantage"); (4) Absence of strategically equivalent substitutes.

Furthermore, company resources can be classified into four main groups namely organisation capital, physical capital, financial capital and human capital. Therefore, the resources of financial capital are all resources that can be utilised by a company in the form of money to implement and design its strategy (Sutanto and Sudarsono, 2018). According to Kapelko (2006), the gauge of performance of business in RBV studies can be divided into two broad categories: (a) operational, which examines the treatment of indicators in non-financial performance measures such as product quality, manufacturing value-added, market share and marketing effectiveness; (b) financial, which emphasises accounting-based gauges such as earning per share or profitability and sales growth keeping in consideration the measurements of the market such as stock-market or market-to-book returns. Therefore, some common examples of specific drivers that impact the performance of companies are the market share of a company, the risk behaviour of a company as well as firm size (Hirsch and Hartmann, 2014).

\section{Literature Review}

In this current study, the past studies were distributed into three main parts: the first segment consists of literature review related to company characteristics and company financial performance; the second segment consists of literature review that used a mixture of company characteristics, macroeconomic factors and company financial performance; the third segment includes non-financial factors and company financial performance.

\subsection{The Relationship Between Company Characteristics and Company Financial Performance}

In Vietnam, Dang et al. (2019) assessed the factors impacting the financial performance proxied (ROA and ROE) from 269 large listed companies in stock exchange for the (2010-2016) period using OLS and quantile regression. Growth rate, short term liquidity, capital structure, receivable management, fixed asset investment and firm size are used. The result showed a negative relationship between financial performance and short-term liquidity, capital structure and fixed assets investment. In contrast, there was a positive relationship between financial performance and firm size. In Jordan, Al-abedallat (2019) analysed the factors affecting the largest financial performance proxied (net income, ROA and ROE) of the largest 11 banks. Capital and assets of the banks utilising camels' model from 2003 to 2017 and multiple linear regression are applied. The results demonstrated a capital adequacy ratio of above $12 \%$ in Jordanians banks; banks with low ratios of ROE and ROA in general were resulted from their serious reservation in fund investment, high level of liquidity and the increased income tax in Jordan. In Indonesia, Sutanto and Sudarsono (2018) analysed the role of internal resources that led to bank competitiveness (ROE and ROA) using panel data set of top 10 commercial banks during the (2013-2015) period. Brand value, branch network, capital adequacy ratio and training as dependent variables, are used. The results showed that bank competitiveness was 
positively correlated with brand value and branch network and negatively correlated with capital adequacy ratio. Moreover, the study showed that training was the only insignificant indicator.

Besides, many studies have been conducted choosing a specific kind of companies or certain sector in the financial markets. In Jordan, Matar and Eneizan (2018) examined the determinants of financial performance (ROA) in 23 manufacturing industrial companies in Amman Stock Exchange for the 2005-2015 period. Liquidity, firm size, financial leverage, profitability and revenue as independent variables by SPSS and E-views package are applied. The results showed a positive nexus between ROA and revenue, profitability and liquidity while firm size and leverage had a negative nexus with ROA. Moreover, all variables have significant impact on the financial performance in accordance with regression analysis. In China, by using Random Effects Model, Fan et al. (2017) investigated the relationship between financial performance and energy efficiency over the period of 2010 to 2014. Six financial indicators were employed in the study namely ROE, return on invested capital (ROIC), return on investment (ROI), ROA, return on sales (ROS) and Tobin's Q. The variables of risk, growth, size and sector were employed as control variables. The results showed that size influenced ROS, ROIC, ROA and ROE positively, whereas growth influenced all indicators positively while risk influenced ROS, ROIC, ROI and ROA negatively. Furthermore, all financial indicators were positively related with energy efficiency except Tobin's Q. In Pakistan, besides using economic value added (EVA), Khan et al. (2015) examined the determinants of financial performance for 145 companies in 10 financial areas namely insurance companies, modarabas, banks, investment banks, venture capital, development financial institution, exchanges companies, leasing companies, mutual funds and housing finance. The study was conducted including company size, company leverage, risk, company liquidity and tangibility as independent variables for the 2008-2012 periods. The results showed that the most effective determinants of financial performance were tangibility, liquidity, risk, size and leverage where size, leverage and liquidity had a positive relationship with financial performance while risk and tangibility had a negative relationship with financial performance in financial companies in Pakistan. Also, Almajali (2012) examined specific determinants that impact the financial performance (ROA) of 25 insurance firms listed in Amman Stock Exchange in Jordan over the period from 2002 to 2007. The study employed company liquidity, company leverage, company age, and company size and management competence index as independent variables. The results revealed that management competence index, company liquidity, company leverage and company size had a statistical and positive impact on the financial performance of insurance firms in Jordan. In contrast, company age had no effect on financial performance of insurance firms in Amman Stock Exchange. The study affirmed the significance of raising company assets for achieving strong financial performance.

\subsection{The Relationship Between Company Characteristics, Macroeconomic Factors and Company Financial Performance}

In the USA, Singh et al. (2019) investigated the factors influencing the financial performance proxied by ROA for 37 united state agricultural cooperatives covering the (2009-2017) period using panel regression analysis. The result presented the sensitivity of US agro cooperative to economic policy uncertainly and the negative relationship between size and profitability. Furthermore, the influence of capital intensity and growth was also reflected in the ROA in Africa. For instance, Abebe and Abera (2019) investigated the determinants of financial performance proxied by ROA and ROE in nine Ethiopian insurance companies during 2010-2015 period using OLS estimation method. The results showed that leverage, age, capital adequacy, loss, size and liquidity were the key determinants of financial performance. Furthermore, the study concluded that financial performance was mainly driven by firm specific factors. Egbunike \& Okerekeoti (2018) investigated the interrelationship between firm characteristics, macroeconomic factors and financial performance (ROA) of manufacturing companies in Nigeria during 2011-2017. The study analysed the impact of exchange rate, interest rate, gross domestic product (GDP) growth rate and inflation rate while liquidity, leverage and size were the firm characteristics. The result showed that GDP growth rate and inflation rate had a significant impact on ROA while exchange rate and interest rate had no significant impact on ROA. Furthermore, firm characteristics including liquidity, leverage and size were significant.

In Asia, by using annual data, Robin et al. (2018) investigated the impact of some policies of financial reforms on the profitability of 12 commercial banks in Bangladesh for 1983-2012 by employing profitability gauges (net interest margin, return on assets and return on equity) through three periods of financial liberalisation. The study employed capital ratio, bank size, asset quality, independent directors and political directors in the board, deregulation, bank concertation ratio, ownership structure, inflation and GDP growth as independent variables. The empirical results showed no significant relationship between ROA and ROE and financial reforms. However, there was a positive and significant relationship between profitability and inflation, capital ratio and bank size. Moreover, the interest margin has increased. GDP growth did not affect bank profitability, whereas profitability had a positive relationship with 
higher loan to assets ratio and greater capital strength in commercial banks in Bangladesh. Furthermore, the results showed that the larger and higher concentration banks were more profitable than smaller and lower concentration ones. The study pointed out that the main profitability drivers were determined by asset quality and capital strength. Also, the study confirmed that raising asset quality and capital base were the vital component of appropriate banking policy in Bangladesh. In addition, Ramli et al. (2018) investigated the influence of determinants of capital structure on company financial performance with the mediation effect of firm leverage in Indonesia and Malaysia for the (1990-2010) period. The result showed that company financial performance was directly affected by certain capital structure determinants. The study observed that company financial performance has a significant and positive correlation with company leverage only with Malaysian sample. Furthermore, the Malaysian companies used external financing to heighten their financial performance. The result also showed that company leverage played a mediating role only in Malaysian sample. Moreover, non-dept tax shield, growth opportunities, interest rate, asset structure and liquidity were the attributes that were indirectly influenced by firm leverage on company financial performance. Mirza and Javed (2013) examined the impact of economic indicators, risk management, ownership structure, corporate governance and capital structure on financial performance proxied by return on equity and shareholder return for 60 companies listed in Karachi Stock Exchange for the 2007- 2011 period. The study employed inflation, long-term debt to total assets, firm risk, business risk, short-term dept to total assets, size, inside ownership, current ratio, debt to equity ratio and block holding as independent variables. The results revealed that risk management, economic factors and ownership structure were the most instrumental factors impacting financial performance of the companies in Pakistan.

In Europe, Burca and Batrin (2014) investigated the factors effecting the financial performance proxied by return on total assets in 21 selected Romanian insurance companies including company size, growth of gross written premiums, total market share, underwriting risk, reinsurance dependence, solvency margin, insurance financial leverage, equity, diversification, investment ratio, retained risk ratio, number of years since the company operates in the Romanian market and growth of GDP per capita in Romania over the period of 2008 to 2012. The findings suggested that financial leverage in insurance, growth and gross written premiums, risk retention ratio, company size, underwriting risk and solvency margin were the specific determinants affecting financial performance in the insurance market of Romania.

\subsection{The Relationship Between Non-financial Factors and Company Financial Performance}

Using fixed effect model, Muhammad et al. (2015) examined the relationship between environmental performance and financial performance proxied by ROA and Tobin's Q in Australia over the period of 2001 to 2010. The study employed additional variables based on extant literature namely firm size, current ratio, dept to equity ratio and dividend yield. The results showed a strong positive relationship between financial performance and environmental performance over the period of 2001 to 2007, which was the pre-financial crisis period. Also, it showed that financial performance and environmental performance had no relationship during the financial crisis period (2008-2010). In Jordan, Alquadah and Malkawi (2014) investigated the effects of world financial crisis and the openness of the economy on the financial performance of the listed banks over the period of 2005 to 2008. The study employed ROE, ROA, earning per share, market share price, market capitalisation and dividend yield as indicators of financial performance while using world financial crisis and the openness of the economy as independent variables. The results showed that the world financial crisis had a statistical and significant impact on all indicators of financial performance of the Jordanian banks except dividend yield, which had a positive but not statistical relationship with the world financial crisis. The results also revealed that the openness of economy had a statistical positive relationship with all indicators of the financial performance for the commercial banks in Jordan. Furthermore, using clustered standard errors, Al-Najjar (2014) investigated the relationship between corporate governance and financial performance proxied by ROA, ROE and stock price returns for 32 tourism listed firms in five Middle Eastern countries namely Oman, Jordan, Bahrain, Kuwait and Egypt over the period of 2005 to 2010. The study employed board independence, board size, percentage change in the corruption index, percentage change in GDP, firm size, firm leverage and cash ratio as independent variables. The results revealed that board size and board independence had a positive relationship with the financial performance of the selected sample. The study also confirmed that the financial crisis period had no negative effect on the firms' financial performance of the selected sample.

Using VECM and granger causality, Abumustafa (2016) investigated the effects of Arab spring on the performance of stock markets in six Arabic countries namely Jordan, Tunisia, Saudi Arabia, Egypt, Kuwait and Bahrain over the period of December 2010 to June 2015. The study utilised daily closing price data and monthly trading value of six stock markets. Furthermore, the study utilised Granger causality between foreign direct investment and trading value of the stock market. The results revealed that Arab spring had and continue to have a negative financial and 
economic effect on the performance of stock markets of most Arab countries. Furthermore, the causality between stock market movement and foreign direct investment in short term has been supported by the economic theory and statistical results. Also, Abdelbaki (2013) investigated the effects of Arab spring on the performance of the stock market in Egypt. Arab spring was proxied by economic instability, political instability and external events associated with the Egyptian revolution. The results revealed that political instability has negatively impacted the stock market performance and played the main role in that effect while economic stability came in second. The results of Granger causality affirmed a long run relationship between the stock market performance and political as well as economic instability in Egyptian economy. In general view, Al-Omari et al. (2015) investigated the general impact of Arab spring on Jordanian hotels using a questionnaire that consists of 12 phrases. The findings revealed that Jordanian hotel sector was statistically and negatively influenced by Arab spring in three fundamental areas, which were financial performance, number of nights and occupation rate.

Despite some studies conducted on the financial sector, the significance of this current study can be summarised theoretically and practically as follow: (1) Theoretically: this study would extend to the economic literature by making major statements on the relationships between financial performance and its determinants (i.e., RS, LQ, LV, $\mathrm{Y}, \mathrm{INF}, \mathrm{FC}$ and AS) to fill the gap in literature. This is because previous studies have been done on the linkages between financial performance and economic growth or between financial performance and its determinants in a specific sector in Amman Stock Exchange. Up to our knowledge, there is no study that has examined the relationships between financial performance and its determinants in Jordan including all sectors in ASE using panel data approach. In addition, this study employed numerous variables as the determinants of financial performance in Jordan that have never been discussed together in previous studies since the past studies only discussed these variables separately. (2) Practically: the empirical analysis of relationships between financial performance and its determinants holds implications for policy makers as well as investors to evaluate the changes in economic conditions. Therefore, this study can help forecasting the most significant factors that lead to improve the financial performance in Jordan's economy in the future. In addition, this study highlighted the determinants of financial performance of financial sector, which considers the most important sector in ASE as this sector forms $64.8 \%$ of the total trading value in ASE (ASE Annual Report, 2017).

On the basis of the past studies (Section 3) and theoretical background (Section 2), the hypotheses of the current study were formulated as follow:

H11: There is no significant statistical impact of the company specific variables (RS, LV and LQ) on the financial performance (ROE) of financial sector in ASE.

H12: There is no significant statistical impact of the macroeconomics variables (GDP and Inflation) on the financial performance (ROE) of financial sector in ASE.

H13: There is no significant statistical impact of the world financial crisis (FC) and Arabic Spring (AS) on the financial performance (ROE) of financial sector in ASE.

\section{Data Sources and Variables Definition}

Balanced panel data of four sub-sectors in the financial sector (banks, insurance, diversified financial services and real estate sub-sectors) over the period of 2005 to 2016 were used by ASTATA 14 package. The data sources were annual financial reports such as the Statement of Financial Position and the Statement of Comprehensive Income of the financial companies in ASE for the period of 2005-2016. Macroeconomic factors were obtained from the website of the World Bank. Meanwhile, non-economic variables were used as dummy variables. Table 1 shows all details of the data used in this paper.

Table 1. Variables definition and past studies used

\begin{tabular}{|c|c|c|c|}
\hline Variables & Data Description & Data Source & Previous studies \\
\hline 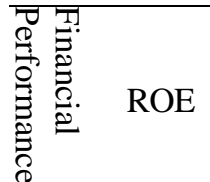 & $\begin{array}{l}\text { Return on equity a proxy of financial } \\
\text { performance }=\text { net income } / \text { total } \\
\text { equity. }\end{array}$ & $\begin{array}{l}\text { Amman stock } \\
\text { exchange }\end{array}$ & $\begin{array}{l}\text { Robin et al. (2018); Fan et al. (2017); Alquadah } \\
\& \text { Malkawi (2014). }\end{array}$ \\
\hline
\end{tabular}




\begin{tabular}{|c|c|c|c|c|}
\hline \multirow{3}{*}{ 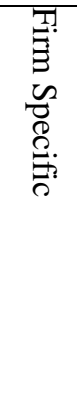 } & $\mathrm{RS}$ & $\begin{array}{l}\text { Company Risk }=\text { EBIT } / \text { Earning } \\
\text { after Interest and Tax. }\end{array}$ & $\begin{array}{l}\text { Amman stock } \\
\text { exchange }\end{array}$ & $\begin{array}{l}\text { Al-abedallat (2019); Dang et al. (2019); Sutanto } \\
\text { and Sudarsono (2018); Fan et al. (2017). }\end{array}$ \\
\hline & LV & $\begin{array}{l}\text { Company Leverage }=\text { total liabilities } \\
\text { of a company / shareholder's equity. }\end{array}$ & $\begin{array}{l}\text { Amman stock } \\
\text { exchange }\end{array}$ & $\begin{array}{l}\text { Abebe \& Abera (2019); Matar \& Eneizan } \\
\text { (2018); Egbunike \& Okerekeoti (2018); Ejigu } \\
\text { (2016). }\end{array}$ \\
\hline & LQ & $\begin{array}{l}\text { Company Liquidity proxied by } \\
\text { current ratio = current assets / } \\
\text { current liabilities }\end{array}$ & $\begin{array}{l}\text { Amman stock } \\
\text { exchange }\end{array}$ & $\begin{array}{l}\text { Dang et al. (2019); Abebe \& Abera (2019) } \\
\text { Matar \& Eneizan 2018; Egbunike \& Okerekeot } \\
\text { (2018); Ejigu (2016). }\end{array}$ \\
\hline \multirow{2}{*}{$\begin{array}{l}3 \\
3 \\
0 \\
0 \\
0 \\
0 \\
0 \\
0 \\
0 \\
0\end{array}$} & $\mathrm{Y}$ & $\begin{array}{l}\text { Gross domestic product a proxy of } \\
\text { economic growth in Jordan. }\end{array}$ & World Bank & $\begin{array}{l}\text { Abebe \& Abera (2019); Egbunike \& Okerekeoti } \\
\text { (2018); Robin et al. (2018); Burca \& Batrin } \\
\text { (2014). }\end{array}$ \\
\hline & INF & $\begin{array}{l}\text { Inflation proxied by annual inflation } \\
\text { rate }\end{array}$ & World Bank & $\begin{array}{l}\text { Abebe \& Abera (2019); Egbunike \& Okerekeoti } \\
\text { (2018); Robin et al., (2018); Mirsa \& Javed, } \\
\text { (2013). }\end{array}$ \\
\hline \multirow[t]{2}{*}{ 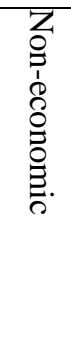 } & $\mathrm{FC}$ & $\begin{array}{l}\text { Stands for the world financial crisis. } \\
\text { D1=0 for the observation during } \\
2005-2007 \text {. D1=1 for the } \\
\text { observation during 2008-2016. }\end{array}$ & $\begin{array}{l}\text { Dummy } \\
\text { Variable }\end{array}$ & $\begin{array}{l}\text { Muhammad et al. (2015); Alquadah \& Malkawi, } \\
\text { (2014); Al-Najjar (2014). }\end{array}$ \\
\hline & AS & $\begin{array}{l}\text { Represents Arabic Spring. D2=0 for } \\
\text { the observation during 2005-2011. } \\
\mathrm{D} 2=1 \text { for the observation during } \\
2012-2016\end{array}$ & $\begin{array}{l}\text { Dummy } \\
\text { variable }\end{array}$ & $\begin{array}{l}\text { Abumustafa (2016); Al-Omari et al. (2015) } \\
\text { Abdelbaki (2013) }\end{array}$ \\
\hline
\end{tabular}

\subsection{Financial Performance Proxy}

ROE was employed in this study as a proxy for financial performance. Return on equity is one of the most suitable and popular ratios to measure and evaluate the return on the investments of the shareholders. Besides, it reflects the ability and the effectiveness of the management to create extra profits for its shareholders. Furthermore, the higher ROE reflects faster growth of the total shareholders equity. ROE is calculated by firm's net income divided by firm's total equity (Alquadah \& Malkawi, 2014; Ramadan, 2009).

\subsection{Firm Specific Variables}

These variables are defined as follow: (a) Company Leverage is measured as the total liabilities of a company divided by shareholder's equity. Company may encounter incapability of arranging the loan payment or collapse of business as a result of high leverage ratio. Accordingly, company's creditability in the business may become weak, causing difficulty in terms of getting future loans (Khan et al., 2015). (b) Company Liquidity measures a company ability to pay off its short-term debt and to stay solvent for at least the short run. In other words, liquidity indicates the ability of a company to meet its day-to-day operations by converting its short assets into cash, which reflects the importance of liquidity in determining the financial performance of companies (Egbunike \& Okerekeoti, 2018; Douglas, 2014). Most of previous studied has used current ratio (current assets divided by current liabilities) to measure the company liquidity (LQ) in the short-term. (c) Company Risk: risk intensity is the main factor of a company's fiscal achievement (Khan et al., 2015). Risk is considered as a vital factor in determining corporate performance due to the high connection between financial risk and corporate performance (Fan et al., 2017). It was argued that companies can take technical innovation and new opportunities in case of low financial risk as it is easier in this circumstance to attract funds. However, companies may face financial collapse due to high agency cost and maximum uncertainty (Khan et al., 2015). Esperanca et al. (2003) pointed out a useful connection among risk of firm (RS) as well as short duration and long duration debt as follows: Risks = EBIT / Earning after Interest and Tax.

\subsection{Macroeconomic Variables}

This paper used two variables: (i) Gross Domestic Product that measures the monetary value of final goods and services produced in a country in a given period. It counts all of the output generated within the borders of a country. GDP is used worldwide to measure the health of nation and global economies (IMF, 2018). Similarly, GDP 
considers the most popular macroeconomic indicator to gauge the activity of an economy because the growth rate of GDP has a significant ability to reflect the state of the economic cycle. Therefore, economic activity is measured globally by GDP as a main gauge (Egbunike \& Okerekeoti, 2018). (ii) Inflation is measured by the general increase in the level of prices for services and the goods throughout a specific period of economy (Matar, 2014). Theoretically, increasing inflation (INF) will lead to a raise in prices, which will be reflected on generating high profit (Butta and Hassan, 2013). Therefore, overall consumer spending will reduce as a result of higher prices, which cause decreasing GDP; nevertheless, inflation itself is not negative. Meanwhile, if the inflation signal has a rapid increase rate, this indicates the possibility of a macroeconomic health (Egbunike \& Okerekeoti, 2018).

\subsection{Non-economic Variables}

In this study, two variables were used to investigate their effects on the finical performance in Jordan, World financial crisis (FC) and Arabic spring (AS). In 2007, world financial crisis was commenced and considered as one of most significant variables (Matar, 2014). The first indication of financial crisis was commenced in USA and quickly stretched to the majority of advanced economics and then speared worldwide (Soufan et al., 2012). In the context of Jordan, micro-economic variables such as GDP per capita, real GDP and GDP growth rate did not give the impact as strong as other countries such as the United States, United Kingdom, United Arab Emirates, Saudi Arabia and Euro Area (Alkhatib et al., 2015). Besides FC, Arabic spring is a series of anti-government uprising impacting Arab countries in North Africa and Middle East since 2010. Furthermore, high unemployment rate, poverty, dictatorship and notable decrease of economic opportunities were enough to be called as Arab spring in several Arab countries including Yemen, Tunisia, Libya, Egypt and Syria. All of these countries had a tremendous impact on their financial performance, which extend to negatively influence most of financial activities and economics in most Arab countries because of investors sensitivity towards new news in terms of the prospects of the economies (Hamouda, 2018). Then, Jordan had a protest movement in terms of political and economic demands (Abumoustafa, 2016). Also, Al-Rfou (2013) pointed out a significant negative impact of Jordan's (Herak) on investment, business activities and Jordan's trade.

\section{Model Specification and Methodology}

Based on theoretical background (Arbitrage Pricing Theory and Resource-Based View Theory), past studies and following the Egbunike \& Okerekeoti (2018), this study used Eq.1 to investigate the impact and relationship between financial performance and its determinants. Pooled OLS, Fixed effect and Random effect techniques have been applied. Also, initials testing of the variables have used, such as descriptive statistics, interrelationships and stationary test.

$$
\mathrm{ROE}_{\mathrm{t}}=\mu+\alpha_{1} \mathrm{RS}_{\mathrm{t}}+\alpha_{2} \mathrm{LQ}_{\mathrm{t}}+\alpha_{3} \mathrm{LV}_{\mathrm{t}}+\alpha_{5} \mathrm{Y}_{\mathrm{t}}+\alpha_{6} \mathrm{INF}_{\mathrm{t}}+\alpha_{7} \mathrm{FC}_{\mathrm{t}}+\alpha_{8} \mathrm{AS}_{\mathrm{t}}+\varepsilon_{\mathrm{t}}
$$

Where these variables are defined in Table land $\varepsilon_{\mathrm{t}}$ represents error terms.

Eq.1 was applied to check the relationship between Return on equity (ROE) as a proxy of financial performance and its determinates in ASE. Therefore, for a quality data, initial techniques, descriptive statistics, interrelationship and stationary tests were used. As stated by Abebe and Abera (2019), both direction and magnitude of the relationships are shown by the correlation coefficients whether they are negative, positive, weak or strong. The lower the values, the weaker the relationship while higher coefficient is an indicator of a strong relationship. The relationship direction shown by the negative sign indicates a negative relationship while the positive sign indicates the opposite. However, the causal effect between variables is not highly supported theoretically by the correlation coefficients. Therefore, it is a correlation matrix between ROE and explanatory variables. For measuring the impact of explanatory variables on financial performance of the financial sector, Pooled OLS, Fixed effect, random effects techniques with Heteroskedasticity and Serial Correlation Robust Standard Error estimation methods were employed.

\section{Empirical Results Analysis}

\subsection{Descriptive Statistics, Interrelationship and Stationary Analysis}

The descriptive analysis of dependent variable (ROE) and explanatory variables are reported as in Table 2. It shows the average indicators of variable computed from the financial statements and deviations, min value and max values from those averages. 
Table 2. Descriptive statistics

\begin{tabular}{llllll}
\hline & Mean & Std. Dev. & Min & Max & Observations \\
\hline ROE & 0.034 & 0.080 & -0.133 & 0.304 & 48 \\
\hline RS & 2.580 & 6.694 & -3.693 & 37.797 & 48 \\
\hline LQ & 2.295 & 1.502 & 0.330 & 4.754 & 48 \\
\hline LV & 2.169 & 2.499 & 0.187 & 8.822 & 48 \\
\hline Y & 4.583 & 2.533 & 2.004 & 8.176 & 48 \\
\hline INF & 3.942 & 3.891 & -0.9 & 14 & 48 \\
\hline
\end{tabular}

As can be observed from Table 2, the mean of ROE was 0.034 and standard deviation was 0.080 . The Min value was -1.33 , whereas the Max value was 0.304 with 48 observations. Meanwhile, the mean of $y$ of financial subsectors on average was 4.583 , which was the highest mean while ROE has the lowest mean of 0.034 . Furthermore, RS has the highest standard deviation of 6.694, whereas ROE has the lowest standard deviation of 0.080 . Furthermore, Table 3 shows the degree of interrelationship between financial performance (ROE) and its determinants for financial sector. It is a measure of linear dependence or linear association between exogenous, endogenous variables and among endogenous variables (Ejigu, 2016).

Table 3. Interrelationship between ROE and its determinates

\begin{tabular}{lllllll}
\hline & ROE & RS & LQ & LV & Y & INF \\
\hline ROE & 1.000 & & & & & \\
\hline RS & -0.444 & 1.000 & & & & \\
\hline LQ & -0.462 & 0.077 & 1.000 & & & \\
\hline LV & 0.520 & 0.055 & -0.708 & 1.000 & & \\
\hline Y & -0.161 & 0.336 & 0.049 & -0.134 & 1.000 & \\
\hline INF & -0.251 & 0.016 & 0.005 & -0.020 & 0.378 & 1.000 \\
\hline
\end{tabular}

Table 3 reveals that the leverage was positively correlated with ROE, which indicates that the more financed companies have higher financial performance. However, there was a negative correlation between ROE and risk, liquidity, inflation and GDP. The negative correlation with risk and liquidity implies that the increase of level of risk or liquidity will push the financial performance of a company in an opposite direction. Likewise, both macroeconomic variables (GDP \& inflation) were negatively correlated with financial performance. This relationship supports the view that GDP growth is not necessarily positively related with company's performance (Abebe \& Abera, 2019). Furthermore, the correlation matrix indicates that all explanatory variables were moderate correlations except the macroeconomic variables, which have a weak correlation.

In order to identify the stationarity of the determinants for financial sector in ASE, Levin, Lin \& Chu test and Hadri LM tests were used to test the group stationary of each variable. The results of these test are shown in Table 4. According to Burca and Batrinca (2014), if the probability is lower than the significance level of $10 \%$, the variable is stationary. Table 4 shows that all variables were stationary on the 1st difference except risk. Also, Hadri LM test confirmed that if the probability is higher than the significance level of $10 \%$, the variable is stationary. Based on that, all variables were stationary on 1st difference except return on equity and leverage. Table 4 displays the group stationary of variables used in the current study at level and 1st difference. 
Table 4. Group stationary of variables

\begin{tabular}{lcllc}
\hline \multirow{2}{*}{ Variables } & Levin-Lin-Chu test & \multicolumn{3}{c}{ Hadri LM test } \\
\cline { 2 - 5 } & $\mathbf{I}(\mathbf{0})$ & \multicolumn{1}{c}{$\mathbf{1 ( I )}$} & $\mathbf{I}(\mathbf{0})$ & $\mathbf{1}(\mathbf{I})$ \\
\hline ROE & $0.933(0.824)$ & $-1.516(0.0647)$ & $1.413(0.078)$ & $1.402(0.08)$ \\
\hline RS & $0.452(0.67)$ & $-0.250(0.40)$ & $5.094(0.000)$ & $-0.645(0.74)$ \\
\hline LQ & $-1.242(0.107)$ & $-4.381(0.000)$ & $0.310(0.378)$ & $-0.832(0.797)$ \\
\hline LV & $1.363(0.913)$ & $-4.967(0.000)$ & $2.453(0.007)$ & $3.135(0.0009)$ \\
\hline Y & $-2.710(0.0034)$ & $2.798(0.0026)$ & $10.409(0.0000$ & $-0.316(0.623)$ \\
\hline INF & $0.996(0.841)$ & $3.348(0.00040$ & $1.946(0.026)$ & $-1.560(0.941)$ \\
\hline
\end{tabular}

Notes: (1) Figures in the parentheses are $\mathrm{P}$ values. (2) The other figures are adjusted t statistic in case of Levin-Lin-Chu test and $\mathrm{z}$ statistic in case of Hadri LM test.

\subsection{Pooled OLS, Random Effect and Fixed Effect Results}

Table 5 demonstrates the results of three models applied in this paper (Pooled OLS, Random effect and fixed effect). Then, diagnostics tools were applied to choose the appropriate model in this study using panel data approach.

Table 5. The stages of choosing appropriate model

\begin{tabular}{llll}
\hline & Pooled OLS & Random Effect & Fixed Effect \\
\hline Constant & -0.004 & -0.004 & -0.017 \\
\hline RS & $-0.002^{*}$ & $-0.002^{*}$ & -0.002 \\
\hline LQ & $0.015^{*}$ & $0.015^{*}$ & $0.038^{* *}$ \\
\hline LV & $0.019^{* * *}$ & $0.019^{* * *}$ & -0.009 \\
\hline Y & 0.004 & 0.004 & 0.007 \\
\hline INF & 0.001 & 0.001 & -0.0001 \\
\hline FC & $-0.095^{* *}$ & $-0.095^{* *}$ & $-0.087^{* *}$ \\
\hline AS & $0.044^{*}$ & $0.044^{*}$ & $0.061^{* *}$ \\
\hline R-squared & 0.4839 & 0.4839 & 0.0006 \\
\hline Observation & 48 & 48 & 48 \\
\hline
\end{tabular}

Notes: (1) Diagnostic tests: Breusch-Pagan LM test $=0.00(1.00)$, Hausman test $=4.94(0.668)$, Multicollinearity (VIF) $=2.56$, Heteroskedasticity $\left(X^{2}\right.$ - stat $)=29.09(0.000)$ and Serial Correlation tests $=18.545(0.0230)$.

$(2) *, * *$ and $* * *$ indicate the significance levels at $10 \%, 5 \%$ and $1 \%$ respectively.

The results of the pooled OLS model and random effect model were similar in which leverage has a positive and significant relationship with financial performance while financial crisis has a negative and significant relationship with financial performance. However, in the case of fixed effect model, liquidity and Arab Spring have a significant and positive relationship with financial performance while financial crisis has a negative and significant relationship with financial performance. Based on the results of three above models, it is significant to choose the most appropriate model. (1) In order to differentiate between random effects model and pooled model, Breusch and Pagan Lagrange multiplier test for random effects was conducted. The null hypothesis supposes that pooled OLS model is more appropriate while the alternative hypothesis supposes that random effects are more appropriate. Therefore, if the P-value $<0.05$, then null hypothesis will be rejected (Law, 2018). P-value in the current study was 1.00, which means that null hypothesis was accepted and then pooled OLS model was more appropriate than random effects. (2) In the case of differentiating between fixed effects model and random effects model, Hausman test was conducted. The null hypothesis supposes that random effects are more appropriate, whereas the alternative hypothesis supposes that fixed effects are more appropriate. Therefore, if $\mathrm{P}$-value $<0.05$, then the null hypothesis will be rejected (Law, 2018). In this study, the P-value was 0.668, meaning that the null hypothesis was accepted and therefore random effects was more appropriate. Then, the results indicate that the Pooled OLS specification was to be preferred. Therefore, to ensure that the results of the Pooled OLS credibility diagnostic tests are needed: (i) multicollinearity 
was detected utilising Variance Inflation Factor (VIF) through measuring the mean of VIF. Therefore, if the mean of $\mathrm{VIF}<10$, that implies no multicollinearity problem. If otherwise, there is a multicollinearity problem (Law, 2018). Therefore, VIF test was conducted to check the multicollinearity between variables. Since the mean of VIF in the current study was 2.56, it concludes that there was no multicollinearity problem. (ii) Heteroskedasticity was detected utilising Modified Wald Statistic for groupwise heteroskedasticity in the residuals of a fixed effect regression model (Green, 2000; Law, 2018). According to Law (2018), $H_{0}$ : There is a Heteroskedasticity, and $H_{1}$ : There is no Heteroskedasticity. This means that if p-value is $<0.05, H_{0}$ will be rejected and a heteroskedasticity problem (the variances are not constant) and vice versa. In the current study, the null hypothesis was rejected as the P-value (0.000) was $<0.05$ which means that there was a heteroskedasticity problem (the variance is not constant). (iii) Serial Correlation was conducted by using Wooldridge test for autocorrelation in panel data. According to Law (2018), $H_{0}$ : There is a serial correlation problem. $H_{1}$ : There is no serial correlation problem. So that if p-value is $<0.05, H_{0}$ will be rejected and implies a serial correlation problem, otherwise, there is no serial correlation problem. In the current study, the null hypothesis was rejected since the P-value $(0.023)$ was $<0.05$, which means that there was a serial correlation problem.

According to the above diagnostic checks, there was a presence of heteroskedasticity and serial correlation problems among variables. Therefore, if heteroskedasticity and serial correlation problem are the only problems occurred through diagnostic tests, then OLS with heteroskedasticity and serial correlation robust standard error estimation is the appropriate test to rectify this problem (Law, 2018). The empirical results of this test are shown in Table 6.

Table 6. The results of the OLS with heteroskedasticity and serial correlation robust standard error

\begin{tabular}{lllllll}
\hline Coef. & Estimate & Robust Std. Err. & $\mathrm{t}$-value & $\mathrm{P}>|\mathrm{t}|$ & {$[95 \%$ Conf. } & Interval] \\
\hline Intercept & -0.005 & 0.045 & -0.10 & 0.923 & -0.148 & 0.138 \\
\hline RS & -0.003 & 0.002 & -1.81 & 0.169 & -0.008 & 0.002 \\
\hline LQ & 0.015 & 0.003 & 4.4 & $0.021^{* * *}$ & 0.004 & 0.026 \\
\hline LV & 0.019 & 0.003 & 6.52 & $0.007 * * *$ & 0.010 & 0.028 \\
\hline Y & 0.004 & 0.003 & 1.44 & 0.245 & -0.005 & 0.014 \\
\hline INF & 0.001 & 0.002 & 0.48 & 0.663 & -0.005 & 0.007 \\
\hline FC & -0.095 & 0.047 & -2.03 & 0.136 & -0.245 & 0.054 \\
\hline AS & 0.044 & 0.021 & 2.10 & 0.127 & -0.023 & 0.112 \\
\hline
\end{tabular}

Notes: (1) Number of observations $=48$, Prob $>F=0.000$, R-squared $=0.4839$.

$(2) *, * *$ and $* * *$ indicate the respective $10 \%, 5 \%$ and $1 \%$ significance levels, respectively.

The analysis of these results (Table 6) confirmed the significant of impact and relationships between financial performance and its determinates in ASE by three groups of variables as shown in Table 1.

(a) Firms specific variables

(1) Risk (RS): It was observed that risk has a negative and insignificant effect on the financial performance of financial sector in ASE at 5\% significant level. Thus, risk cannot be taken as a key determinant of financial performance of financial sector in ASE. This result is in line with the study of Burca and Batrin (2014) and in contrast with the study of Mirza and Javed (2013) reporting the positive relationship between risk and financial performance in Pakistan. Also, the study of Khan et al. (2015) reported a negative relationship between risk and financial performance in Pakistan, whereas the study of Fan et al. (2017) reported no relationship between risk and financial performance in China. (2) Liquidity (LQ): It had a positive and significant effect on performance as the positive coefficient of liquidity (0.015) implies that when the level of liquidity (liquid assets) increase by one Jordanian dinar (JD), financial performance will also move in the same direction by $0.015 \mathrm{JD}$. The higher the level of liquidity, the more the ability to indemnify loses and fulfil the company's claims (Abebe \& Abera, 2019). Thus, liquidity can be taken as a key determinant of financial performance of financial sector in ASE. This result is supported by the research conducted by Abebe \& Abera (2019), Matar and Eneizan (2018), Egbunike \& Okerekeoti (2018), Khan et al. (2015) and Almajali et al. (2012). In contrast, Dang et al. (2019), Ramli et al. (2018) and Mirza and Javed (2013) reported negative relationship between liquidity and financial performance. (3) Leverage (LV): It had a positive and significant impact on financial performance at $1 \%$ significant level. The positive sign of 
coefficient (0.019) implies that an increase in external financing (debt) by one JD leads to an increase in financial performance by JD (0.019). It predicts that the performances of highly levered companies are going to have high performance and suggests that debt financing is better than equity financing (Abebe \& Abera, 2019). This result is in line with the findings of Egbunike \& Okerekeoti (2018), Khan et al. (2015) and Almajali et al. (2012). In contrast, Abebe \& Abera (2019), Matar and Eneizan (2018), Ramli et al, (2018) and Burca and Batrin (2014) reported a negative relationship between leverage and financial performance.

(b) Macroeconomic Variables

(1) Gross domestic product (Y): The result shows a positive and insignificant influence on the financial performance of financial sector in ASE. This is supported by the research conducted by Abebe \& Abera (2019), Robin et al. (2018) and Burca and Batrin (2014). In contrast, Egbunike \& Okerekeoti (2018) and Ramli et al. (2018) reported the positive relationship between GDP and financial performance. Thus, GDP cannot be taken as a key determinant of financial performance for the financial sector in ASE. (2) Inflation (INF): inflation has insignificant impact and the effect was positive. This result is in line with the study of Abebe \& Abera (2019). In contrast, Egbunike \& Okerekeoti (2018), Ramli et al, (2018) and Mirza and Javed (2013) reported a negative relationship between inflation and financial performance while Robin et al. (2018) reported the positive relationship between inflation and financial performance Thus, inflation was rejected as a key determinant of financial performance for financial sector in ASE.

(c) Non-Economic variables

(1) Financial Crisis (FC) has a negative and insignificant effect on the financial performance of financial sector in ASE at 5\% significant level. This result is supported by the research conducted by Muhammad et al. (2015). Nevertheless, this is contrary to Alquadah and Malkawi (2014) study conducted in Jordan, which showed that financial crisis had a significant and negative influence on financial performance. Thus, Financial Crisis was rejected as a key determinant of financial performance for financial sector in ASE. (2) Arab Spring (AS) has a positive effect on the financial performance of financial sector in ASE but the impact was insignificant. This is contrary to Abumustafa (2016) and Al-Omari et al. (2015) studies, which showed that Arab Spring had a significant and negative influence on financial performance. Thus, Arab Spring was rejected as a key determinant of financial performance of financial sector in ASE.

\section{Conclusion and Recommendations}

This paper aims to highlight the impact of firm's specific and macroeconomics variables on the financial performance of Jordanian financial firms listed in Amman Stock Exchange. Also, it investigates and explores the interrelationship between firm characteristics (liquidity and leverage), macroeconomic factors (gross domestic product and inflation) and non-economic factors (global financial crisis and Arab spring) and financial performance of sub-sectors in financial sector for the period 2005 to 2016. Panel data techniques (Pooled OLS, Random effect and fixed effect methods) have been employed in this study. Findings showed that liquidity, leverage have a significant effect on financial performance while risk, macroeconomic factors and non-economic factors have insignificant effect on financial performance of financial sector in ASE. These results were supported by earlier studies as discussed in the previous section.

The importance of the current study stems from linking the components of the financial performance of financial companies in ASE. The results that can be accessible are of a high degree of importance in understanding the reasons of fluctuation and underperformance of financial companies in Jordan, which can avoid the collapse of financial companies and their exposure to financial problems. In addition, studying the relationship between financial performance and firm characteristics, macroeconomic and non-economic factors can shed some light on the response of financial markets to firm characteristics, macroeconomic and non-economic factors for similar emerging markets. Thus, it can be claimed that financial performance fluctuation is basically linked to firm characteristics. Therefore, the empirical analysis of relationships among financial performance and its determinants holds implications for policy makers as well as investors to evaluate the changes in economic conditions.

Based on results of this study, greater attention should be paid to firm specific factors especially liquidity and leverage as they are the key determinants of financial performance in Jordan. Moreover, the leverage position of a company should be adequately monitored by managers as highly leveraged companies might be at risk of bankruptcy if they do not have ability to make payments on their debt. Meanwhile, managers should monitor the liquidity posture of a company to fulfil the company's claims. At last, it is recommended that the number of independent variables is increased to generate a more useful information and further enhance the scope of future studies. Also, future researchers may consider comparing the performance of financial sectors with non-financial sectors. 


\section{References}

Abdelbaki, H. H. (2013). The impact of Arab spring on stock market performance. British Journal of Economics, Management \& Trade, 3(3), 169-185. https://doi.org/10.9734/BJEMT/2013/3768

Abebe, A. K., \& Abera, M. T. (2019). Determinants of financial performance; Evidence from Ethiopia insurance companies. Journal of Accounting, Finance and Auditing Studies, 5(1), 155-172. https://doi.org/10.32602/jafas.2019.7

Abumustafa, N. I. (2016). Investigating the Arab stock markets during Arab spring. Journal of Asset Management, 17, 313-318. https://doi.org/10.1057/jam.2016.8

Al Qudah, A. M., \& Malkawi, E. (2017). Financial crisis, openness of the economy and the financial performance of Jordanian listed banks: Analytical study. Arab Economic and Business Journal, 9(1), 61-66. https://doi.org/10.1016/j.aebj.2011.10.001

Al-abedallat, A. Z. (2019). The factors affecting the performance of the Jordanian banks using camels model. European Journal of Scientific Research, 152(2), 116-127.

Alkhatib, H. B., Sharabati, A. A., Alhorani, A., Tabieh, M., Qtaisht, T., \& Obeidat, Z. (2015). The impact of the global financial crisis on the Jordanian GDP. Global Advanced Research Journal of Management and Business Studies, 4(9), 398-406.

Almajali, A. Y., Alamro, S. A., \& Al-Soub, Y. Z. (2012). Factors affecting the financial performance of Jordanian insurance companies listed at Amman stock exchange. Journal of Management Research, 4(2), $260-266$. https://doi.org/10.5296/jmr.v4i2.1482

Al-Najjar, B. (2014). Corporate governance, tourism growth and firm performance: Evidence from publicly listed tourism firms in five Middle Eastern countries. Tourism Management, 42, 342-351.

Al-Najjar, N. (1998). Factor Analysis and Arbitrage Pricing in Large Asset Economies. Journal of Economic Theory, 78(2), 231-262. https://doi.org/10.1006/jeth.1997.2369

Al-Omari, I., Ali, M. M., Mahmoud, R. M., \& Jawabreh, O. A. (2015). The Arab spring impacts on the Jordanian hotels sector. International Journal of Humanities and Social Science, 5(4), 159-171.

Al-Rfou, A. N. (2013). The impact of Jordan spring on business and investment activities from respondents' perspective. Interdisciplinary Journal of Contemporary Research in Business, 4(12), 1256-1263.

Al-Smadi, R. W. (2015). Dynamics relationship between foreign direct investment and its determinants in Jordan. Unpublished Doctoral Thesis, Universiti Tenaga Nasional, Malaysia. Amman Stock Exchange. Retrieved from http://www.ase.com.jo

Barney, J. B. (1991). Firm resources and sustained competitive advantage. Journal of Management, 17(1), 99-120. https://doi.org/10.1177/014920639101700108

Bekhet, H. A., \& Al-Smadi, R. W. (2015). Determinants of Jordanian foreign direct investment inflows: Bounds testing approach. Economic Modelling, 46, 27-35. https://doi.org/10.1016/j.econmod.2014.12.027

Bekhet, H. A., \& Matar, A. A. (2012). Risk-adjusted performance: A two-model approach application in Amman stock exchange. International Journal of Business and Social Science, 3(7), 34-45.

Bekhet, H. A., \& Matar, A. A. (2013). Co-integration and causality analysis between stock market prices and their determinates in Jordan. Economic Modelling, 35, 508-514. https://doi.org/10.1016/j.econmod.2013.07.012

Bekhet, H. A., \& Yasmin, T. (2014). Assessment the global financial crisis Effects on energy consumption and economic growth in Malaysia: An input-output analysis. International Economics, 140, 49-70. https://doi.org/10.1016/j.inteco.2014.07.003

Bekhet, H. A., Alsmadi, A. M., \& Khudari, M. (2020). Effects of Internal and External Factors on Profitability of Jordanian Commercial Banks: Panel Data Approach. International Journal of Financial Research, 11(5), 359-375. https://doi.org/10.5430/ijfr.v11n5p359

Bhutta, N. T., \& Hasan, A. (2013). Impact of firm specific factors on profitability of firms in food sector. Open Journal of Accounting, 2, 19-25. https://doi.org/10.4236/ojacct.2013.22005

Connor, G., \& Korajczyk, R. (1986). Performance measurement with the arbitrage pricing theory. Journal of Financial Economics, 15(3), 373-394. https://doi.org/10.1016/0304-405X(86)90027-9 
D’Angelo, E. (2018). A resource-based perspective to assess firms' profitability in the food industry: Evidence from the Italian cheese industry. European Scientific Journal, 14(4). https://doi.org/10.19044/esj.2018.v14n4p1

Dioha, C., Mohammed, N., \& Okpanachi, J. (2018). Effect of firm characteristics on profitability of listed consumer goods companies in Nigeria. Journal of Accounting, Finance and Auditing Studies, 4(2), 14-31.

Douglas, J. E. (2014). Bank liquidity requirements: An introduction and overview. The Brookings Institution. Retrieved from https://www.brookings.edu/research/bank-liquidity-requirements-an-introduction-and-overview

Egbunike, C. F., \& Okerekeoti, C. U. (2018). Macroeconomic factors, firm characteristics and financial performance: A study of selected quoted manufacturing firms in Nigeria. Asian Journal of Accounting Research, 3(2), 142-168. https://doi.org/10.1108/AJAR-09-2018-0029

Ejigu, S. N. (2016). Determining internal factors affecting financial performance of insurance companies in Ethiopia. Research Journal of Commerce \& Behavioural Science, 5(6), 9-21.

Esperanca, J. P., Ana, P. M., \& Mohamed, A. G. (2003). Corporate debt policy of small firms: An empirical (re)examination. Journal of Small Business and Enterprise Development, 10(1), 62-80. https://doi.org/10.1108/14626000310461213

Fan, L. W., Pan, S. J., Liu, G. Q., \& Zhou, P. (2017). Does energy efficiency affect financial performance? Evidence from Chinese energy-intensive firms. Journal of Cleaner Production, 151, 53-59.

Gallo, A. (2016). A refresher on return on assets and return on equity. Harvard Business Review. Retrieved from https://hbr.org/2016/04/a-refresher-on-return-on-assets-and-return-on-equity

Grinblatt, M., \& Titman, S. (2002). Financial Market and Corporate Strategy (2nd ed.). New York: McGraw-Hill Irwin.

Hamouda, F. (2018). Stock repurchase and Arab spring empirical evidence from the MENA region. The Journal of Finance and Data Science, 1(4), 29-43. https://doi.org/10.1016/j.jfds.2017.11.003

Hirsch, S., \& Hartmann, M. (2014). Persistence of firm-level profitability in the European dairy processing industry. Agricultural Economics, 45(51), 53-63. https://doi.org/10.1111/agec.12129

Hoang, T. V., Hung, N. H., Tran, M. D., Vu, T. T., \& Pham, Q. T. (2019). Determinants Influencing Financial Performance of Listed Firms: Quantile Regression Approach. Asian Economic and Financial Review, 9(1), 78-90. https://doi.org/10.18488/journal.aefr.2019.91.78.90

Hunt, S. D. (1999). The strategic imperative and sustainable competitive advantage: public policy implications of resource-advantage theory. Journal of the Academy of Marketing Science, 27(2), 144-159.

IMF. (2018). Annual report. Retrieved from www.imf.org/external/pubs/ft/fandd/basics/gdp.htm

IMF. (2019). Annual report. $\quad$ Retrieved from https://www.imf.org/ /media/Files/Publications/CR/2019/1JOREA2019001.ashx

Issah, M., \& Antwi, S. (2017). Role of macroeconomic variables on firms' performance: Evidence from the UK. Cogent Economics \& Finance, 5(1), 1-18. https://doi.org/10.1080/23322039.2017.1405581

Kaguri, W. A. (2013). Relationship between firm characteristics and financial performance of life insurance companies in Kenya. Unpublished Master's Thesis, University of Nairobi, Kenya.

Kapelko, M. (2006). Evaluating efficiency in the framework of resource-based view of the firm: Evidence from Polish and Spanish textile and clothing industry. Research Work. Universität Autonoma de Barcelona.

Khan, M. K., Nouman, M., \& Imran, M. I. (2015). Determinants of financial performance of financial sectors (An assessment through economic value added). Retrieved from https://mpra.ub.uni-muenchen.de /81659/

Khrawish, H., Siam, W., \& Khrawish, A. (2011). Determinants of Islamic bank profitability: Evidence from Jordan. Middle Eastern Finance and Economics, (13). Retrieved from http://www.eurojournals.com/MEFE.htm

Kumar, R. (2014). A Study on Financial Performance of Vijaya Bank in Kadur. Unpublished master's thesis, Kuvempu University, Karnataka, India.

Matar, A. A. (2014). Co-integration analysis of the relationship between the stock price index and its determinants: Evidence from Amman stock exchange. Unpublished doctoral thesis, Universiti Tenaga Nasional, Malaysia.

Matar, A. A., \& Eneizan, B. M. (2018). Determinants of financial performance in the industrial firms: Evidence from Jordan. Asian Journal of Agricultural Extension, Economics \& Sociology, 22(1), 1-10. https://doi.org/10.9734/AJAEES/2018/37476 
Mirza, S. A., \& Javed, A. (2013). Determinants of financial performance of a firm: Case of Pakistani stock market. Journal of Economics and International, 5(2), 43-52. https://doi.org/10.5897/JEIF12.043

Muhammad, N., Scrimgeour, F., Reddy, K., \& Abidin, S. (2015). The relationship between environmental performance and financial performance in periods of growth and contraction: Evidence from Australian publicly listed. Journal of Cleaner Production, 102, 324-332. https://doi.org/10.1016/j.jclepro.2015.04.039

Nour, A. I., \& Sharabati, A. A. (2014). Impact of global financial crisis on Amman stock exchange (ASE) market Amman-Jordan. Baghdad College Economic Sciences Journal, 1-18.

Ramadan, A. H. (2009). Determinants of capital structure and the firm's financial performance: An application on the UK capital market. Unpublished doctoral thesis, University of Surrey, UK.

Ramadan, I. (2012). The Validity of the arbitrage pricing theory in the Jordanian stock market. International Journal of Economics and Finance, 4(5), 177-185. https://doi.org/10.5539/ijef.v4n5p177

Ramli, N., Latan, N., \& Solovida, G. (2018). Determinants of capital structure and firm financial performance -APLS-SEM approach: Evidence from Malaysia and Indonesia. The Quarterly Review of Economic and Finance, 71(2019), 148-160. https://doi.org/10.1016/j.qref.2018.07.001

Robin, I., Salim, R., \& Bloch, H. (2018). Financial performance of commercial banks in the post-reform era: Further evidence from Bangladesh. Economic Analysis and Policy, 58, 43-54. https://doi.org/10.1016/j.eap.2018.01.001

Salah, I. (2010). Effect of the Financial Crisis on the Middle East. The Global Business Law Review, 1(7), 99-108.

Samhan, H., \& Al-Khatib, A. (2015). Determinants of financial performance of Jordan Islamic bank. Research Journal of Finance and Accounting, 6(8), 37-48.

Singh, K., Misra, M., Kumar, M., \& Tiwari, V. (2019). A study on the determinants of financial performance of U.S. agricultural cooperatives. Journal of Business Economics and Management, 20(4), 633-647. https://doi.org/10.3846/jbem.2019.9858

Slijper, T. (2017). The impact of strategies on the financial performance of European investor-owned dairy processors. Unpublished master's research, Wageningen University.

Soufan, T., Abdul-Khaliq, S., \& Abu Shihab, R. (2012). Causes of the global financial crisis and its effects on the Arab countries. Canadian Social Science, 8(6), 153-159.

Sutanto, E. M., \& Sudarsono, D. (2018). Empirical analysis of firm resources in the banking industry in Indonesia: A resource-based view. International Journal of Business and Society, 19(3), 587-595.

Toms, S. (2010). Value, profit and risk: Accounting and the resource-based view of the firm. Accounting, Auditing \& Accountability Journal, 23(2), 647-670. https://doi.org/10.1108/09513571011054927

Walker, D. (2001). Exploring the Human Capital Contribution to Productivity, Profitability and the Market Evaluation of the Firm. Retrieved from http:/wwwlib.umi.com/dissertations

Watson, D., \& Head, A. (2010). Corporate Finance: Principles and Practice (5th ed.). England: Pearson Education Limited.

Zainudin, R., Mahdzan, N., \& Leong, E. (2018). Firm-specific internal determinants of profitability performance: An exploratory study of selected life insurance firms in Asia. Journal of Asia Business Studies, 12(4), 533-550. https://doi.org/10.1108/JABS-09-2016-0129

Zeitun, R., Tian, G., \& Keen, S. (2007). Macroeconomic determinants of corporate performance and failure: Evidence from an emerging market the case of Jordan. Corporate Ownership and Control, 5(1), 179-194. https://doi.org/10.22495/cocv5i1c1p2

\section{Copyrights}

Copyright for this article is retained by the author(s), with first publication rights granted to the journal.

This is an open-access article distributed under the terms and conditions of the Creative Commons Attribution license (http://creativecommons.org/licenses/by/4.0/). 